\title{
Current Knowledge on Listeria monocytogenes Biofilms in Food-Related Environments: Incidence, Resistance to Biocides, Ecology and Biocontrol
}

\author{
Pedro Rodríguez-López ${ }^{1}{ }^{(\mathbb{D}}$, Juan José Rodríguez-Herrera ${ }^{1}$, Daniel Vázquez-Sánchez ${ }^{2} \mathbb{B}^{\mathbb{B}}$ and \\ Marta López Cabo ${ }^{1, *}$ \\ 1 Department of Microbiology and Technology of Marine Products (MICROTEC), Instituto de Investigaciones \\ Marinas (IIM-CSIC), 6, Eduardo Cabello, 36208 Vigo, Spain; pedrorodriguez@iim.csic.es (P.R.-L.); \\ juanherrera@iim.csic.es (J.J.R.-H.) \\ 2 "Luiz de Queiroz" College of Agriculture (ESALQ), University of São Paulo (USP), 11, Av. Pádua Dias, \\ 13418-900 São Paulo, Brazil; danielvazquezsanchez@gmail.com \\ * Correspondence: marta@iim.csic.es; Tel.: +34-986-231-930
}

Received: 20 April 2018; Accepted: 1 June 2018; Published: 5 June 2018

\begin{abstract}
Although many efforts have been made to control Listeria monocytogenes in the food industry, growing pervasiveness amongst the population over the last decades has made this bacterium considered to be one of the most hazardous foodborne pathogens. Its outstanding biocide tolerance capacity and ability to promiscuously associate with other bacterial species forming multispecies communities have permitted this microorganism to survive and persist within the industrial environment. This review is designed to give the reader an overall picture of the current state-of-the-art in L. monocytogenes sessile communities in terms of food safety and legislation, ecological aspects and biocontrol strategies.
\end{abstract}

Keywords: bacteriocins; biocides; biofilm; food industry; food safety; Listeria monocytogenes; resistance

\section{Listeria monocytogenes, a Food Safety Concern}

Listeria monocytogenes is a ubiquitous pathogen that can stem from a febrile gastroenteritis to a severe invasive illness (listeriosis), leading to septicaemia, encephalitis, endocarditis, meningitis, abortions and stillbirths, among others syndromes [1,2]. The incidence of listeriosis is low amongst the general population, with 0.46 and 0.24 cases per 100,000 population in 2015 in the European Union and the United States respectively [3,4]. However, L. monocytogenes was responsible for many foodborne outbreaks with high hospitalisation and mortality rates worldwide, especially affecting pregnant women, the elderly and individuals with compromised immune systems. In particular, L. monocytogenes caused more foodborne outbreaks between 2005 and 2015 in the EU (83) than in the US (47), resulting in 757 and 491 cases, respectively [5-13]. In contrast, a higher number of cases required hospitalisation in the US (428) than in the EU (332), leading to more deceases (82 and 61 deaths respectively) and a higher mortality rate (24 and $16 \%$ of deceases related to foodborne outbreaks in the US and in the EU, respectively).

In spite of modifications to legal regulations, ready-to-eat (RTE) meats and dairy products are still the predominant vehicles involved in the main listeriosis outbreaks which have occurred since 2008, as well as other "low risk" products such as fruit and vegetables (Table 1). In addition to this, no consensus has been achieved among international food authorities in regards to the microbial criteria for L. monocytogenes [14]. As a matter of example, The United States Department of Agriculture (USDA) and the Food and Drug Administration (FDA) implemented a "zero tolerance" policy for 
L. monocytogenes contamination of RTE food products $[15,16]$. In contrast, the European Commission Regulation No. 2073/2005 (amended by EC No. 1441/2007) permits levels of L. monocytogenes up to $100 \mathrm{CFU} / \mathrm{g}$ in RTE foods placed on the market during their shelf-life, except in those intended for infants or for special medical purposes, in which must be absent in $25 \mathrm{~g}$ of product $[17,18]$. Canada, Australia and New Zealand also permit levels of L. monocytogenes lower than $100 \mathrm{CFU} / \mathrm{g}$ for RTE foods in which the growth of this pathogen is limited throughout the stated shelf-life, but it must be absent in $25 \mathrm{~g}$ of those which can support its growth $[16,19,20]$. According to the Chinese Centre for Food Safety (CFS) levels of L. monocytogenes of 10-100 CFU/g are allowed in RTE commercialised in China, except in those refrigerated (not frozen) in which it must be absent in $25 \mathrm{~g}$ of product [21,22]. In Brazil, the use of L. monocytogenes as microbial criteria is limited to cheese, in which it must be absent in $25 \mathrm{~g}$ of product [23]. Curiously, many food companies follow the national regulations for products commercialised in their own country, but not foreign regulations for products that they export, leading to products with different standards of quality and safety. These actions can involve eventual problems of cross-contamination between the processing chains and a serious risk to consumers due to this lack of universal legislation. Therefore, an international consensus in microbial criteria for foodstuffs must be reached.

Table 1. Main outbreaks of foodborne listeriosis since 2008.

\begin{tabular}{|c|c|c|c|c|c|c|}
\hline Year & Country & Food Product & Cases & Hospitalisations & Deaths & Ref. \\
\hline 2008 & Canada & Delicatessen meat & 57 & 47 & 24 & [24] \\
\hline 2009-2010 & Austria, Germany and Czech Republic & "Quargel" cheese & 34 & 34 & 8 & [25] \\
\hline 2009-2012 & Portugal & Fresh cheeses & 30 & 30 & 11 & [26] \\
\hline 2010 & Texas (US) & Diced celery & 10 & 10 & 5 & [27] \\
\hline 2011-2012 & 28 US states & Cantaloupes & 147 & 143 & 33 & [28] \\
\hline 2012 & 14 US states & Brand ricotta salata cheese & 22 & 20 & 4 & [29] \\
\hline 2012 & Spain & Latin-style fresh cheese & 2 & 2 & 2 & [30] \\
\hline 2013-2014 & Switzerland & RTE salad & 32 & 32 & 4 & [31] \\
\hline 2013-2014 & Denmark & RTE meat products & 41 & 41 & 17 & [32] \\
\hline 2014-2015 & 12 US states & Caramel apples & 35 & 34 & 7 & [33] \\
\hline 2015 & 10 US states & Soft cheeses & 30 & 28 & 3 & [34] \\
\hline 2016 & 9 US states & Packaged salads & 19 & 19 & 1 & [3] \\
\hline 2016 & 4 US states & Frozen vegetables & 9 & 9 & 3 & [13] \\
\hline
\end{tabular}

In the food industry, L. monocytogenes can persist for months or even years on floors and equipment and in drains of food-processing facilities $[35,36]$. This is mainly due to its ability to survive under food-related conditions that are stressful for other bacteria, such as refrigerated temperatures, desiccation, heat and high salt content [37-40], and its ability to form biofilms [41,42]. The application of ineffective cleaning and disinfection procedures in food-processing environments, particularly in locations of difficult access, also increases the risk of establishment and growth of L. monocytogenes and, thus, generate continuous food product contamination $[43,44]$. The identification of particular niches in a food-processing facility, the validation of the efficacy of sanitation procedures applied and the continuous monitoring of the presence and reestablishment in food-processing environments are therefore required to improve the control of L. monocytogenes.

Livestock and produce farms are considered potential primary sources for the introduction of human pathogenic L. monocytogenes into the food chain and food-processing plants. In fact, L. monocytogenes was detected in cattle, silage, animal feeds, manure and growing grass, among others [45-48]. Nevertheless, soil, water and vegetation of natural and urban environments can also serve as reservoirs of L. monocytogenes [49-51].

L. monocytogenes involved in most human listeriosis cases has been isolated from RTE foods post-processed in retail facilities [52,53]. The application of inadequate post-processing procedures such as improper manipulation (e.g., bacterial transfer from operator's hands and gloves, cutting boards or scales among others) or the use of contaminated slicing machines were the main cause of contamination 
in RTE foods [53-56]. In addition, L. monocytogenes is also found on non-food contact surfaces such as floors, drains, sinks, and walk-in cooler shelves of retail facilities [57,58]. L. monocytogenes can also proliferate due to temperature fluctuations in coolers during distribution and commercialisation of food products [59]. Moreover, this pathogen is detected in domestic environments [60-62] and public restaurants [63-65]. Several listeriosis outbreaks are also associated with foods purchased from or provided in hospitals and health care centres [66-68]. A limited knowledge of food safety, as well as an inappropriate attitude and hygiene of food handlers can directly affect the quality of the product $[69,70]$. Therefore, guidelines for prevention of L. monocytogenes contamination and persistence should be widely spread.

\section{Efficacy of Food Industry Sanitisers against L. monocytogenes}

According to published data, in Europe, around five trillion euros are invested annually for the implementation of hygienisation systems in food-related industrial environments. Nevertheless, the levels of bacterial contamination in processed food products is still a major issue of concern, with the increasing incidence of $L$. monocytogenes being remarkable if we take into account the notified cases of listeriosis [71]. The current tolerance to disinfectants in L. monocytogenes has been a topic of concern in the context of the food industry and public health regarding foodborne pathogens. The presence of high bacterial concentrations and the interference with organic matter due to insufficient cleaning prior to disinfection diminishes the activity and thus the efficacy of disinfectants commonly used in industrial premises [72]. This does not necessary mean that the quantity used is lower, but that the effective concentration of the antimicrobial is less than expected, compared to the initial amount deployed. However, anthropologic factors such as failure in dosage or inadequate rinsing are also responsible for the generation of tolerances due to the formation of areas in which sub-lethal concentrations of the disinfectant are present [73]. Additionally, it has also been stated that tolerance to certain disinfectants may contribute to the persistence of L. monocytogenes in the food industry [74].

In this section, the behaviour and further tolerance mechanisms to quaternary ammonium, chlorine and acid compounds in L. monocytogenes, are reviewed.

\subsection{Quaternary Ammonium Compounds}

Among biocides, quaternary ammonium compounds (QACs) are undoubtedly, one of the most commonly used disinfectants in the food industry efficient against bacteria, algae, fungi, spores, viruses and mycobacteria even at low concentrations [75]. QACs are active in the membrane of bacteria, casing disruption in the phospholipid bilayer and subsequent cellular content leakage causing eventual bacterial death [75]. They are stable, surface-active agents presenting low toxicity and little affected by organic matter, which make them very adequate for food industry purposes.

The described mechanisms underneath tolerances to QACs are diverse and are strongly influenced by the environment and the genetic background of each particular strain [76]. Considering the latter, a study carried out by Liu et al. [77] demonstrated how the presence of antimicrobials' sublethal concentrations can increase the possibility of oxidative stress of the cell due to an increasing concentration of free radicals in the cytoplasm. As a result, this can promote the activation of various genetic cascades like the apparition of de novo mutations due to the triggering of the SOS-response [78]. The overuse (or misuse) of QACs, may enhance the selection of new genetic elements that can be horizontally transferred [78,79]. This fact poses an additional element for the development of new forms of tolerances in L. monocytogenes, thus dwindling the number of options for treatment in industrial contexts that could finally enhance the biofilm formation to this pathogen [74].

Active efflux pumps are considered so far, the main mechanism for L. monocytogenes tolerance to QACs. This was early described by Aase et al. [80], demonstrating an extrusion of ethidium bromide outside the cell in BAC resistant and BAC adapted strains, which not only indicated the presence of an efflux pump but also that this mechanism is intrinsic to L. monocytogenes and can be activated by a sublethal exposure to BAC. Subsequent studies demonstrated that these efflux 
pumps are chromosomically encoded and that the exposure to QACs leads to an overexpression of them [76]. Despite the general agreement on this major strategy for QAC tolerance, there is still some controversy about the origin of the genetic determinants coding for efflux pumps. As a matter of example, Dutta et al. [79] demonstrated that in BAC-tolerant L. monocytogenes from various sources, the $b c r A B C$ cassette was present in $98.6 \%$ of isolates. Contrarily, Ebner et al. [81] identified the qacH as the main genetic determinant in BAC resistant isolates from different food matrices, and the lack of correlation between this genotype, the isolation source, the biofilm formation capability and the serotype. More recently, a new efflux pump, emrE, has been described in L. monocytogenes conferring cross-resistance to BAC and other antimicrobials [82].

Genetic mobile elements also play an important role in the dissemination of resistance genes among L. monocytogenes. Among, bcrABC-carrying isolates, it has been proposed that the transmission and subsequent integration into the chromosome, together with other resistance genes, has been mediated via transposon-containing plasmids [79]. In addition to this, Müller et al. [83] have described in L. monocytogenes the structure of Tn6188, harbouring the qacH gene. Ulterior investigation regarding this mobile element, has demonstrated that cells expressing qacH-encoded efflux pumps, showed increased MICs to BAC and other QACs, and also a decreased susceptibility to ethidium bromide [84].

Moreover, in L. monocytogenes, biofilm formation itself is a cause of increased tolerance to QACs due to the alterations in the membrane fluidity of the cell [85]. These alterations are mainly because of a decrease in the proportion of iso- $\mathrm{C} 15$ and anteiso-C15 branched-chain fatty acids (BCFA) together with an significant increase in the quantity of saturated fatty acids (SFA) [86]. Consequently, the membrane hydrophobicity is increased, thus promoting further adherence to surfaces [87]. Similar modifications have been described in cells exposed to sublethal concentrations of BAC [73] or to cold stress [87].

\subsection{Chlorine-Based Compounds}

Chlorines are cheap and straightforwardly used antimicrobials active against bacteria, fungi and algae. Different chlorine-based compounds such as sodium hypochlorite, chlorine dioxide gas or aqueous chlorine dioxide have been proven to be active against L. monocytogenes [88].

Due to their fast-oxidising nature, they interact with cellular membranes or penetrate directly into the cell forming $\mathrm{N}$-chloro groups that react with the cellular metabolism due to the interference with key enzymes [89]. With this regard, Valderrama et al. [90] found a L. monocytogenes reduction of about $4 \log \mathrm{CFU} / \mathrm{mL}$ in brine chilling solutions treated with $3 \mathrm{mg} / \mathrm{mL}$ chlorine dioxide with just $90 \mathrm{~s}$ contact time. Nevertheless, in L. monocytogenes, proper chlorine efficacy seems to be age-dependent since the thickness of the cell wall in young cultures is higher, thus protecting the cells from these sanitisers. In this line, El-Kest and Marth [91] demonstrated that a solution of $1 \mathrm{mg} / \mathrm{mL}$ of free chlorine during 10 min sufficed to reduce 4.27 orders of magnitude in 48-h-old L. monocytogenes Scott A cultures, whereas in 24-h-old cultures the reduction was only of 2.88 orders of magnitude.

Tolerance development against chlorine-based sanitisers has been described so far to be unlikely in L. monocytogenes cell suspensions [92,93]. However, Lundén et al. [94] showed that continuous transfers culture in increasing concentrations of sodium hypochlorite can promote the increase in MIC values of this disinfectant. Additionally, decreased activity of chlorine-based sanitisations have been observed not because of intrinsic factors but to interactions with external elements such as organic matter [91,92,95] or divalent cations [90].

In L. monocytogenes biofilms, the efficacy of chlorine solutions has been proven to greatly depend on the biofilm substrate. Hence, Bremer et al. [96] observed a significant higher proportion of eliminated cells of L. monocytogenes when grown on stainless steel coupons compared to those grown on polyvinyl chloride surfaces. These results were also in concordance with those obtained by Pan et al. [97] demonstrating higher tolerance to chlorine treatments in those biofilms grown in Teflon compared to those on stainless steel. Moreover, it has been observed that the adaptation of planktonic cells and subsequent sessile growth on stainless steel makes biofilms to be more tolerant to chlorine, independently of the subtype, cellular density of the biofilm and its morphology [98]. Additionally, 
some authors also described a cross-resistance in favour of tolerance to chlorine in L. monocytogenes biofilms previously treated with peroxide-based products, thus indicating that the mechanisms responsible for oxidising agents' tolerance may have a common nature in L. monocytogenes [97].

The effects of chlorination in L. monocytogenes multispecies biofilms have also been investigated. Norwood et al. [99] showed that this pathogen is able to endure concentrations higher than $1000 \mathrm{ppm}$ of free chlorine in a continuous co-culture with Staphylococcus xylosus and Pseudomonas fragi on stainless steel. In contrast, other authors have found that in co-culture with Flavobacterium spp., a slightly acidic solution containing $400 \mathrm{ppm}$ of free chlorine is enough to reduce the load both bacteria up to undetectable levels [96].

\subsection{Acid Compounds}

Acids are strong oxidisers able to interfere with cellular phospholipid bilayers and cytosolic material causing irreversible damage (e.g., disruption of proton motive force) and subsequent death to cells $[100,101]$. However, L. monocytogenes is able to adapt to low $\mathrm{pH}$ environments generated by natural processes (e.g., lactic fermentation) or artificially induced (e.g., acidification of water for cleaning systems) by means of different mechanisms. This not only allows this pathogen to survive in the environment, but could also increases its virulence since it further helps the bacterium to survive into the gastrointestinal tract and macrophage phagosome [102].

In spite of the fact that acid adaptation is a transient state in L. monocytogenes [103], it enhances the survival of this pathogen in the food industry, while also providing the bacterium with higher protection against other environmental insults [103]. Following this line, Phan-Thanh et al. [104] demonstrated that pre-exposure to mild acidic conditions ( $\mathrm{pH} 5.5,2 \mathrm{~h}$ ) increased its endurance against lethal acidic, temperature $\left(52{ }^{\circ} \mathrm{C}\right)$, salinity $(25-30 \% \mathrm{NaCl})$ and alcoholic $(15 \%)$ shocks. These effects are even more evident when the acid adaptation takes places gradually [102,105]. Additionally, it has been demonstrated that sublethal acid adaptation deeply alters the intracellular protein pattern expression, being more evident as the $\mathrm{pH}$ decreases $[104,106]$, and that this differential pattern is strain-dependent [104].

There are different ways described in the literature in which L. monocytogenes can adapt to acidic conditions, all of them focused on the maintenance of the intracellular homeostasis. Among them, the glutamate decarboxylase (GAD) system is considered one of the major mechanisms [107]. This involves the GAD enzyme, which promotes the irreversible conversion of cytosolic glutamate to a neutral compound, the $\gamma$-aminobutyrate (GABA), by irreversible decarboxylation of the first [103]. The synthesis of GABA has a dual protective role: firstly, it consumes an intracellular proton during the process, with the subsequent increase of the $\mathrm{pH}$ inside of the cell [103]. Additionally, the extrusion of GABA outside the cell via a glutamate:GABA antiporter, contributes to the slight neutralisation of the $\mathrm{pH}$ outside the cell and the restarting of the metabolic pathway [102]. In food systems, it has been demonstrated that in glutamate-rich products, the survival rate of L. monocytogenes is significantly improved [107]. In addition to glutamate:GABA antiporter, other proton pumps such as $\mathrm{F}_{0} \mathrm{~F}_{1}$-ATPase have also been proposed as active mechanisms to maintain homeostasis in acidified environments [108].

Similarly with exposure to QACs, acidic conditions modify the composition of the cytoplasmic membrane, altering the iso- and anteiso-BCFAs ratio. Giotis et al. [109] tested the response of L. monocytogenes $10403 \mathrm{~S}$ to mild acid conditions, demonstrating that the total anteiso/iso ratio increased as the culture $\mathrm{pH}$ decreased. This was further demonstrated by Zhang et al. [110] in L. monocytogenes cultured in presence of various organic acids, concluding not only that the relative proportions of BCFAs were significantly altered but also that the mechanism underneath this adaptation was shared.

In biofilms, the acid-tolerance in L. monocytogenes seems to be strain dependent. In this line, Ibusquiza et al. [111] showed that the resistance threshold to peracetic acid between three different strains depended not only on the strain, but also the age of the biofilm and the substrate where the biofilms were grown on. These results were in accordance with those obtained by Lee et al. [112,113]. Furthermore, in addition to its overall resistance, biofilm formation is also affected 
when L. monocytogenes is exposed to acid compounds generally enhancing its adherence $[114,115]$ even though there is evidence that early exposure to acidic conditions does not modify the ulterior biofilm formation capacity [116]. Additionally, accompanying strains, such as lactic acid bacteria, can exert a protective effect to L. monocytogenes in mixed-species biofilms, increasing its tolerance to acidic sanitisers [117].

\section{Microbial Interactions and Resistance of L. monocytogenes Mixed-Species Biofilms}

It is accepted that bacteria live in nature associated with another species forming structured multispecies biofilms [118]. Their life in communities makes unavoidable interspecies interaction and its impacts biofilm ecology.

Microbial communities can be defined as multispecies associations with complex structures that normally suppose important ecological advantages to the individual species present. In fact, it is accepted that biofilms represent a microbial phenotype with an explicit organisation level in which microorganisms are involved in intracellular interactions that can be competitive, cooperative or even neutral, depending on the microbial species involved and the environmental conditions [119].

Interspecies interactions are especially relevant in L. monocytogenes considering it is considered a poor biofilm former when compared to other bacterial species [120]. Several previous studies have addressed the influence of the accompanying microbiota in the number of adhered viable cells of L. monocytogenes in the corresponding mixed biofilm. There is a risk associated with the increased attachment of L. monocytogenes on food processing surfaces precolonised by other bacterial genera. In general, the number of adhered L. monocytogenes was increased, decreased or unaltered depending on the accompanying bacterium [121]. As an example, Norwoord and Gilmour [122] demonstrated that higher L. monocytogenes numbers in monocultures compared with the multispecies biofilms formed after its association with Staphylococcus xylosus and Pseudomonas fragi. Rodríguez-López et al. [123] explored the association capacity of ten different accompanying strains with L. monocytogenes when forming dual-species biofilms. Outcomes demonstrated a deleterious effect of several accompanying strains on L. monocytogenes present on biofilms in 4 out of 10 different combinations checked. On the contrary, in other studies it has been showed that accompanying strains increase the level of adherence of L. monocytogenes in the mixed biofilm [123-126]. In summary, literature highlights that phenomena of adhesion/aggregation between different bacterial genera cannot be predicted since different environmental conditions can be encountered within the different niches.

Generally, previously reported studies consider that the amount of adhered viable cells in biofilms is directly related with its resistance to antimicrobials $[127,128]$. Nevertheless, in L. monocytogenes, viable biomass present in the biofilm does not give any certain indication about the difficulty of this pathogen to be eliminated from a given contamination site. In fact, a study carried out by Midelet et al. [129] demonstrated that interaction of L. monocytogenes with Kocuria varians results in higher density of the first but made its detachment easier.

The specific location of L. monocytogenes in the mixed microbial communities seems to be crucial when thinking on the effective elimination of the cells from contaminated surfaces or foods. Sasahara and Zottola [130] described initially interactions between Pseudomonas sp. and L. monocytogenes in biofilms and claimed on the need of a primary coloniser such as Pseudomonas sp. for L. monocytogenes to attach. Curiously, subsequent confocal microscopic studies highlight that L. monocytogenes locates at the bottom layers of the dual biofilms with Pseudomonas fluorescens. Moreover, the authors argue that L. monocytogenes cells have to make their way towards the biofilm bottom across the matrix [131].

Specific interspecies interactions existing in nature inside the biofilm are difficult to understand because it is impossible to empirically reproduce the strategies adopted by each species of the bacterial community to finally enhance the fitness of the biofilm consortium [119]. In spite of this, several advances have been achieved, mainly referred to the role of the accompanying microbiota.

As part of biofilm fitness, resident microbiota could protect $L$. monocytogenes to external stimuli such as food processing and/or disinfection conditions. This has been a matter of concern for biofilm 
researchers in the last decades. However, due to the complexity associated with the experimental work within biofilms, most of the published articles had been carried out with dual-species biofilms, which can be considered an excessive simplification of the realistic situation. Lactobacillus plantarum protected L. monocytogenes from the action of BAC and peracetic acid (PAA) [117]. Similarly, Saá Ibusquiza et al. [132] also showed that the presence of Pseudomonas putida increased the resistance of several strains of L. monocytogenes to BAC and PAA.

On the other hand, a recent study carried out by Papaioannou et al. [133] demonstrated, using a more realistic approach, that L. monocytogenes adhesion to stainless steel decreased $\left(<10^{2} \mathrm{CFU} / \mathrm{cm}^{2}\right)$ due to co-culture with indigenous microbiota commonly found in fish industry such as Pseudomonas spp., Enterobacteria or sulfide-producing bacteria. Furthermore, they postulated that this adhesion impairment was possibly one of the causes of an observed increased sensitivity to two common industrial disinfectants (Hypofoam and Divosan).

In spite of the difficulty associated with this type of studies, advances in microscopic and high throughput sequencing methodologies will permit to go deeper in the knowledge of species interactions in order to improve the hygienic design and the control of foodborne pathogens.

\section{Biosanitation of L. monocytogenes Biofilms Using Lactic Acid Bacteria and Bacteriocins}

The removal of microorganisms from food premises cannot be currently conceived without the use of conventional biocides. However, this practice has not been completely successful, and some issues have arisen. For instance, the emergence of resistant (or tolerant) strains $[134,135]$ and a highly decreased effectiveness in the presence organic material [136] or in "harbourage sites" [121].

Huge efforts have been therefore conducted to search for new strategies of control of foodborne pathogens, with particular reference to L. monocytogenes [137-139]. This search has also included cost-effectiveness, environmentally friendly nature and low toxicity to humans as further major requirements. As a result, a number of promising alternatives have been identified, such a lactic acid bacteria (LAB), bacteriocins or bacteriophages, enzymes and surfactants (mainly as anti-adhesion and detachment agents), essential oils, electrolysed oxidising water and ozone, photocatalysts, ionising and UV radiation or ultrasonication, among others.

It is widely known that the microbiota present in food facilities can enhance or inhibit the colonisation of surfaces by L. monocytogenes [119,125,140]. Accordingly, Fox et al. [141] proposed to influence the microbiome in favour of antilisterial species as a strategy to reduce the presence of L. monocytogenes. However, the microorganisms are, in general, undesirable in food premises, since they may promote food spoilage or cause food safety problems. This is may not be the case for LAB, particularly for those having probiotic properties.

Many different $\mathrm{LAB}$ and several bacteriocins are known to be highly active against Gram-positive bacteria, particularly against L. monocytogenes $[142,143]$. In addition, the presence of antilisterial structural bacteriocins genes in LAB has been recently reported [144]. Accordingly, several studies have examined the potential of LAB and their bacteriocins as a tool for the control of biofilms of L. monocytogenes in food facilities. This last section of this review is intended to briefly outline some of the most significant results of these studies.

\subsection{Preventing Biofilm Formation}

Nisin is, without any doubt, the most studied bacteriocin. Moreover, among bacteriocins, only nisin has been granted a generally recognised as safe (GRAS) status by the FDA and approved for use as a food additive (additive number E234) within the European Union. Initial studies were, therefore, focused on the effectiveness of nisin and nisin-producing Lactococcus lactis subsp. lactis strains against biofilms. An early study by Bower et al. [145] already showed that nisin films adsorbed on silica surfaces inhibited the growth of L. monocytogenes. In addition, high nisin concentrations were found to be lethal to attached cells. 
Since then, a number of studies have evaluated the potential of several bacteriocins to prevent adhesion and biofilm formation of L. monocytogenes on different plastic and metallic substrates, specifically nisin [146-148], enterocins [148,149] and sakacin 1 [150]. Although these studies were conducted using from pure bacteriocins to cell-free extracts, results clearly show that bacteriocins may delay but not prevent biofilm formation completely. In fact, only enterocin AS-48 (conditioned on polystyrene surfaces) was reported to be able to completely inhibit biofilm formation for at least $24 \mathrm{~h}$, but longer times of study were not tested [149]. Similarly, Winkelströter et al. [150] also observed a noticeable inhibition of initial stages of biofilm formation for up to $24 \mathrm{~h}$ in the presence of a cell-free neutralised supernatant of Lactobacillus sakei 1 (containing non-purified sakacin 1), but regrowth of biofilms took place subsequently, which was attributed to a possible lack of competition for nutrients or a selection of bacteriocin-tolerant phenotypes.

The effect of Lactococcus lactis CNRZ 150, a nisin-producing strain, against the attachment of L. monocytogenes was also examined [151]. These authors underlined an additional advantage of using bacteriocin-producing LAB over bacteriocins, that is, competitive inhibition limiting nutrient supply and, accordingly, two different approaches were addressed. The first, "deferred adhesion" (later defined as exclusion mechanism), consists of testing the effect of pre-formed L. lactis biofilms. In the second, "simultaneous adhesion" (later, competition mechanism), the effect is tested by co-culturing L. lactis and L. monocytogenes. In both scenarios, attachment of L. monocytogenes and subsequent biofilm formation was effectively prevented.

Considering that it is highly likely that L. monocytogenes encounters resident biofilms rather than solid abiotic surfaces in food-processing environments [152], the effectiveness of LAB against the attachment of L. monocytogenes has been interchangeably tested in terms of exclusion or competition mechanisms in many subsequent studies. This effect has been defined as competitive exclusion. As a result, a high number of different strains has been shown to be highly effective: Enterococcus durans [153,154], Enterococcus faecium [146], L. lactis [153-155], Lactobacillus plantarum and Enterococcus casseliflavus [156], Leuconostoc mesenteroides [157], L. sakei [150,158], Pediococcus acidilactici, Lactobacillus amylovorus and Lactobacillus animalis [159], Lactobacillus acidophilus, Lactobacillus casei, Lactobacillus paracasei and Lactobacillus rhamnosus [160], and Lactobacillus paraplantarum [161], among others.

Generally, bacteriocin-producing strains have been found to be more effective than non-bacteriocin-producing strains against biofilm formation by L. monocytogenes. This was clearly found for E. faecium [146], L. mesenteroides [157] and L. sakei [150]. However, the effectiveness of LAB can be also due to other antimicrobial metabolites, such as lactic acid and other organic acids which also decrease $\mathrm{pH}$, as well as biosurfactants that can additionally prevent adhesion [155,162].

Additionally, competition for adhesion sites and nutrients was also shown to inhibit biofilm formation [163,164]. Interestingly, a study performed by Habimana et al. [164] showed by confocal laser-scanning microscopy of dual-species biofilms formed by co-culture with L. lactis that L. monocytogenes cells were located in the bottom layers of biofilms, entirely covered by L. lactis. In addition, modelling revealed that $L$. monocytogenes would be, in their own words, smothered by competitors and forced into a survival lifestyle, rather than into proliferation or colonisation processes. This inhibition would mainly occur during the initial phases of biofilm formation, essentially due to longer generation time and latency of L. monocytogenes. A similar effect had been already detected by Leriche et al. [151], who found that L. monocytogenes became permanent resident in dual-species biofilms when the inoculum size was high $\left(10^{8} \mathrm{CFU} / \mathrm{mL}\right)$, even though high densities of L. lactis were able to outcompete and prevent $L$. monocytogenes to resume growth on surfaces. In keeping with these studies, it is worth to indicate that L. monocytogenes was found to be more resistant to disinfection in dual-species biofilms with L. plantarum than in single-species biofilms, particularly when outnumbered by L. plantarum, which seems to indicate a protective effect of the latter [117]. 


\subsection{Removal of Biofilms}

In line with these above mentioned studies, different comparative studies have shown that the effectiveness of LAB against pre-formed biofilms of L. monocytogenes (approach known as displacement mechanism) is significantly lower than on adhesion and biofilm formation by competitive exclusion [158-160]. That is, acting early would seem to be most appropriate to prevent biofilm formation. A similar conclusion can be drawn by comparing results from two different studies conducted by Zhao et al. [153,154], despite the effectiveness of displacement being considerably increased by extending treatments with LAB for up to 3 weeks.

Similarly, nisin was found to act rather slowly and, more importantly, with a limited effectiveness against pre-formed biofilms of L. monocytogenes $[111,155]$. This was attributed to a reduced ability to diffuse into the matrix and reach cells. Subsequent studies have confirmed that nisin does not seem to be practical as a surface sanitiser on its own $[165,166]$. Biofilms were also highly resistant to treatments with enterocin [149] and a semi-purified curvacin extract of L. sakei [158]. Concentrated cell-free supernatants from several bacteriocin-producing LAB did not have strong effects on pre-formed biofilms of L. monocytogenes either [167]. On the contrary, an important effect on biofilms was recently claimed for both nisin and enterocin [148], but rather high cell densities could be still clearly observed by scanning electron microscopy following treatments.

\subsection{Combined Treatments}

L. monocytogenes can develop tolerance and even resistance to bacteriocins if exposed to sub-inhibitory concentrations $[168,169]$, and this decreases substantially the efficacy of treatments. Thus, Bower et al. [145] had already shown that coating surfaces with nisin did not inhibit the adhesion of nisin-resistant $L$. lactis. Combining LAB or bacteriocins with other antimicrobial factors may provide a greater effect, something that has been widely known for a long time. Thus, Leriche et al. [151] had already suggested the use of hurdle technology-like approaches to overcome bacteriocin resistance. Some studies have tested this strategy on biofilms of L. monocytogenes.

Of note, the treatment of floor drains of food-processing facilities with one strain of L. lactis subsp. lactis and other of E. durans greatly reduced the contamination with L. monocytogenes $[154,170]$. This combination should reduce the likelihood that L. monocytogenes developed tolerance to nisin too. Thus, most drains were found to remain free of detectable L. monocytogenes for several weeks after completing treatments.

Remarkably, bioencapsulation of thermally-treated fermentates of two strains of Carnobacterium maltaromaticum and one of Enterococcus mundtii, plus a relatively high nisin concentration, in an alginate matrix supported by a mesh-type fabric was highly effective against biofilms of L. monocytogenes [171]. Bioencapsulation allows bacteriocins to be slowly released, which seems to be more effective than large doses [172], as long as the emergence of resistance does not occur. This biocontroller eliminated $L$ monocytogenes from biofilms formed in floor gutters in a fish processing plant after only $48 \mathrm{~h}$ of contact time, but was rather ineffective against biofilms formed on plastic surfaces (i.e., Teflon and rubber), where they were thinner and the attachment was stronger than on stainless steel. Importantly, conventional biocides did not reduce the effectiveness of the biocontroller. They were thus used jointly to achieve maximum effectiveness.

As an alternative to combine different $\mathrm{LAB}$, some researchers have proposed to combine bacteriocins with different modes of action. This involved merging nisin-a class I bacteriocin-with enterocin-belonging to class $\mathrm{IIb}-$, a bacteriocin produced by enterococci, was highly active against biofilms of nisin-resistant L. monocytogenes. Four-fold less of both bacteriocins were required and, importantly, no cross-resistance was detected [148]. On the contrary, cross-resistance for nisin and class IIa bacteriocins has been detected $[173,174]$. Nonetheless, previous studies demonstrated that some enterocins can present cytotoxicity upon epithelial cells [175], hence, whether they can be safe for use in food environments still remains to be clarified. 
Combining bacteriocins with conventional biocides also seems an attractive strategy to reduce the likelihood of colonisation by resistant variants. Thus, the combination of enterocin AS-48 with different commercial sanitisers (quaternary ammonium compounds, bis-phenols or guanides) was found to be much more effective than any single treatment, but this effect was not observed with oxidising agents [149]. This approach would also allow conventional biocides to be used in lower amounts while increasing efficacy, which is highly important to reduce toxicity to humans and in the environment.

\subsection{Final Considerations}

A controlled application of LAB seems a very promising approach to prevent or even remove L. monocytogenes from food facilities basically as a result of a high competitive potential for adhesion sites and nutrients, and the production of some growth-inhibiting compounds, majorly bacteriocins. Moreover, the ability of LAB to spread and colonise surfaces can make them highly suitable as an alternative treatment for difficult-to-reach locations, where L. monocytogenes is not easily removed by routine cleaning and disinfection.

LAB have been safely used by humans for centuries in food production and preservation. However, they have no legal status for use as biosanitisers in the food industry. Accordingly, some issues have arisen concerning the use of some LAB. Prerequisites for a safe use need to be clearly defined.

Ideally, bacteriocin-producing LAB with no cross-resistance should be strategically combined to increase efficacy and prevent the emergence of bacteriocin-resistant phenotypes. In this sense, studies intended to validate different combinations of LAB should be encouraged. However, LAB generally join pre-existing polymicrobial biofilms in food processing environments rather than forming new structures. Consequently, this coexisting microbiota as well as temperature (which fluctuates rather significantly), the surface or soiling, among other factors, can eventually affect attachment, growth and bacteriocin production of each $\mathrm{LAB}$, and therefore the effectiveness of treatments. Treatments should be therefore optimised individually. Unfortunately, only a small number of studies have addressed in situ testing $[154,170,171]$, which makes it highly likely that applications are far from being straightforward. The design of strategies for in situ application of LAB in the food industry is thus needed.

\section{Conclusions and Future Perspectives}

There is no doubt that the recalcitrance of L. monocytogenes in foodstuffs is greatly influenced by the ubiquitous presence of its biofilm among food contact and non-food contact surfaces within food-processing premises [121]. Despite the great advances that have been made over the last few decades in the field of food safety, several outbreaks (Table 1) with high rates of morbidity and mortality, especially within the so-called YOPI (young, old, pregnant, immunosupressed) group, are still reported [71,176].

Understanding the various genetic and physiological underlying mechanisms leading to antimicrobial resistance as well as the influence on L. monocytogenes of pre-existing resident/transient microbiota and vice versa, are nowadays considered as key factors to developing fast, efficient, safe and cost-effective treatments in order to improve the environmental control of this foodborne pathogen.

Additionally to biocontrol as presented in this review, there is a significant amount of ongoing investigation developed by several groups focused on the design of ad hoc antibiofilm strategies such as enzymes [177], bacteriophages [178] or combined strategies [179]. Nevertheless, the rapid adaptation undergone by the different members of sessile communities makes us always being one step behind. Hence, the development of preventive rather than disinfecting strategies based on case-by-case approaches appears as wide field of research to go in-depth to eventually ensure the quality and safety of foodstuffs consumed in the society.

Author Contributions: Conceptualisation of the reivew: M.L.C. Writing (original manuscript): P.R.-L., J.J.R.-H., D.V.-S. and M.L.C. Formatting, reviewing and editing: P.R.-L. 
Acknowledgments: Authors P.R.-L., J.J.R.-H. and M.L.C. acknowledge the Spanish Ministerio de Economía, Industria y Competitividad (MINEICO) for its financial support (Project: SOLISTA; AGL2016_78549). Author D.V.-S. was financially supported by a research grant of the São Paulo Research Foundation (FAPESP, 2014/20590-0).

Conflicts of Interest: The authors declare no conflict of interest.

\section{References}

1. Charlier, C.; Perrodeau, É.; Leclercq, A.; Cazenave, B.; Pilmis, B.; Henry, B.; Lopes, A.; Maury, M.M.; Moura, A.; Goffinet, F.; et al. Clinical features and prognostic factors of listeriosis: The MONALISA national prospective cohort study. Lancet Infect. Dis. 2017, 17, 510-519. [CrossRef]

2. Vázquez-Boland, J.A.; Kuhn, M.; Berche, P.; Chakraborty, T.; Domi, G.; González-zorn, B.; Wehland, J. Listeria Pathogenesis and Molecular Virulence Determinants Listeria Pathogenesis and Molecular Virulence Determinants. Clin. Microbiol. Rev. 2001, 14, 584-640. [CrossRef] [PubMed]

3. CDC. Foodborne Diseases Active Surveillance Network (FoodNet). Available online: https://www.cdc.gov/ foodnet/reports/data/infections.html (accessed on 12 January 2018).

4. EFSA. The Euroean Union summary report on trends and sources of zoonsoes, zoonotic agents and food-borne outbreaks in 2015. EFSA J. 2016, 14, 4634. [CrossRef]

5. EFSA. The Community summary report on trends and sources of zoonoses, zoonotic agents, antimicrobial resistance and foodborne outbreaks in the European Union in 2005. EFSA J. 2006, 94. [CrossRef]

6. EFSA. The Community Summary Report on Trends and Sources of Zoonoses, Zoonotic Agents, Antimicrobial Resistance and Foodborne Outbreaks in the European Union in 2006. EFSA J. 2007, 130. [CrossRef]

7. EFSA. The Community summary report on trends and sources of zoonoses and zoonotic agents in the European Union in 2007. EFSA J. 2009, 223. [CrossRef]

8. EFSA. The European Union summary report on trends and sources of zoonoses, zoonotic agents and food-borne outbreaks in 2009. EFSA J. 2011, 9. [CrossRef]

9. EFSA. Trends and Sources of Zoonoses and Zoonotic Agents and Food-borne Outbreaks in 2011. EFSA J. 2013, 11, 3129. [CrossRef]

10. EFSA. The European Union Summary Report on Trends and Sources of Zoonoses, Zoonotic Agents and Food-borne Outbreaks in 2012. EFSA J. 2014, 12. [CrossRef]

11. EFSA. The European Union summary report on trends and sources of zoonoses, zoonotic agents and food-borne outbreaks in 2013. EFSA J. 2015, 13, 3991. [CrossRef]

12. EFSA. The European Union summary report on trends and sources of zoonoses, zoonotic agents and food-borne outbreaks in 2014. EFSA J. 2015, 13, 4329. [CrossRef]

13. CDC. National Outbreak Reporting System (NORS). Available online: https://www.cdc.gov/nors/data/ dashboard/faq-using-dashboard.html (accessed on 20 January 2018).

14. Hoagland, L.; Ximenes, E.; Ku, S.; Ladisch, M. Foodborne pathogens in horticultural production systems: Ecology and mitigation. Sci. Hortic. 2018, 236, 192-206. [CrossRef]

15. USDA-FSIS. Verification Activities for the Listeria monocytogenes (Lm) Regulation and the Ready-To-Eat (RTE) Sampling Program; United States Department of Agriculture, Food Safety and Inspection Service: Washington, DC, USA, 2014; p. 48.

16. FDA. Guidelines for the Microbiological Examination of Ready-To-Eat Foods. Available online: https:// www.foodstandards.gov.au/code/microbiollimits/documents/GuidelinesforMicroexam.pdf (accessed on 3 May 2018).

17. European Commission. Commission Regulation (EC) No 2073/2005 of 15th November 2005 on microbiological criteria for foodstuffs. Off. J. Eur. Union 2005, L338, 1-26.

18. European Commission. Commission Regulation (EC) No 1441/2007 of 5 December 2007 amending Regulation (EC) No 2073/2005 on microbiological criteria for foodstuffs. Off. J. Eur. Union 2007, L322, 12-29.

19. Policy on Listeria Monocytogenes in Ready-to-Eat (RTE) Foods. Available online: https: / / www.canada.ca/content/dam/hc-sc/migration/hc-sc/fn-an/alt_formats/pdf/legislation/pol/ policy_listeria_monocytogenes_2011-eng.pdf (accessed on 20 January 2018). 
20. Australia New Zealand Food Standards Code-Schedule 27-Microbiological Limits in Food. Available online: https: / /www.legislation.gov.au/Details/F2017C00323 (accessed on 20 January 2018).

21. Centre for Food Safety. Microbiological Guidelines for Food. For Ready-To-Eat Food in General and Specific Food Items; Food and Environmental Hygiene Department: Hong Kong, China, 2014.

22. Centre for Food Safety. Microbiological Guidelines for Ready-To-Eat Food. Available online: http://blpd. dss.go.th/micro/ready.pdf (accessed on 3 May 2018).

23. ANVISA. Regulamento Técnico Sobre os Padrões Microbiológicos Para Alimentos; Diário Oficial da República Federativa do Brasil: Brasília, Brazil, 2001; p. 48.

24. Thomas, M.K.; Vriezen, R.; Farber, J.M.; Currie, A.; Schlech, W.; Fazil, A. Economic Cost of a Listeria monocytogenes Outbreak in Canada, 2008. Foodborne Pathog. Dis. 2015, 12, 966-971. [CrossRef] [PubMed]

25. Schoder, D.; Stessl, B.; Szakmary-Brändle, K.; Rossmanith, P.; Wagner, M. Population diversity of Listeria monocytogenes in quargel (acid curd cheese) lots recalled during the multinational listeriosis outbreak 2009/2010. Food Microbiol. 2014, 39, 68-73. [CrossRef] [PubMed]

26. Magalhães, R.; Almeida, G.; Ferreira, V.; Santos, I.; Silva, J.; Mendes, M.M.; Pita, J.; Mariano, G.; Mancio, I.; Sousa, M.M.; et al. Cheese-related listeriosis outbreak, Portugal, March 2009 to February 2012. Eurosurveilance 2015, 20. [CrossRef]

27. Gaul, L.K.; Farag, N.H.; Shim, T.; Kingsley, M.A.; Silk, B.J.; Hyytia-Trees, E. Hospital-Acquired Listeriosis Outbreak Caused by Contaminated Diced Celery-Texas, 2010. Clin. Infect. Dis. 2013, 56, 20-26. [CrossRef] [PubMed]

28. McCollum, J.T.; Cronquist, A.B.; Silk, B.J.; Jackson, K.A.; O'Connor, K.A.; Cosgrove, S.; Gossack, J.P.; Parachini, S.S.; Jain, N.S.; Ettestad, P.; et al. Multistate Outbreak of Listeriosis Associated with Cantaloupe. N. Engl. J. Med. 2013, 369, 944-953. [CrossRef] [PubMed]

29. Heiman, K.E.; Garalde, V.B.; Gronostaj, M.; Jackson, K.A.; Beam, S.; Joseph, L.; Saupe, A.; Ricotta, E.; Waechter, H.; Wellman, A.; et al. Multistate outbreak of listeriosis caused by imported cheese and evidence of cross-contamination of other cheeses, USA, 2012. Epidemiol. Infect. 2016, 144, 2698-2708. [CrossRef] [PubMed]

30. Castro, V.; Escudero, J.M.; Rodriguez, J.L.; Muniozguren, N.; Uribarri, J.; Saez, D.; Vazquez, J. Listeriosis outbreak caused by Latin-style fresh cheese, Bizkaia, Spain, August 2012. Eurosurveillance 2012, 17, 3-5. [CrossRef]

31. Stephan, R.; Althaus, D.; Kiefer, S.; Lehner, A.; Hatz, C.; Schmutz, C.; Jost, M.; Gerber, N.; Baumgartner, A.; Hächler, H.; et al. Foodborne transmission of Listeria monocytogenes via ready-to-eat salad: A nationwide outbreak in Switzerland, 2013-2014. Food Control 2015, 57, 14-17. [CrossRef]

32. Jensen, A.K.; Nielsen, E.M.; Björkman, J.T.; Jensen, T.; Müller, L.; Persson, S.; Bjerager, G.; Perge, A.; Krause, T.G.; Kiil, K.; et al. Whole-genome sequencing used to investigate a nationwide outbreak of listeriosis caused by ready-to-eat delicatessen meat, Denmark, 2014. Clin. Infect. Dis. 2016, 63, 64-70. [CrossRef] [PubMed]

33. Angelo, K.M.; Conrad, A.R.; Saupe, A.; Dragoo, H.; West, N.; Sorenson, A.; Barnes, A.; Doyle, M.; Beal, J.; Jackson, K.A.; et al. Multistate outbreak of Listeria monocytogenes infections linked to whole apples used in commercially produced, prepackaged caramel apples: United States, 2014-2015. Epidemiol. Infect. 2017, 145, 848-856. [CrossRef] [PubMed]

34. CDC. Multistate Outbreak of Listeriosis Linked to Soft Cheeses Distributed by Karoun Dairies, Inc. Available online: http:/ / www.cdc.gov/listeria/outbreaks/soft-cheeses-09-15/index.html (accessed on 21 January 2018).

35. Ferreira, V.; Wiedmann, M.; Teixeira, P.; Stasiewicz, M.J. Listeria monocytogenes persistence in food-associated environments: Epidemiology, strain characteristics, and implications for public health. J. Food Prot. 2014, 77, 150-170. [CrossRef] [PubMed]

36. Jami, M.; Ghanbari, M.; Zunabovic, M.; Domig, K.J.; Kneifel, W. Listeria monocytogenes in Aquatic Food Products-A Review. Compr. Rev. Food Sci. Food Saf. 2014, 13, 798-813. [CrossRef]

37. Doyle, M.E.; Mazzotta, A.S.; Wang, T.; Wiseman, D.W.; Scott, V.N. Heat resistance of Listeria monocytogenes. J. Food Prot. 2001, 64, 410-429. [CrossRef]

38. Gardan, R.; Cossart, P.; Labadie, J. Identification of Listeria monocytogenes genes involved in salt and alkaline-pH tolerance. Appl. Environ. Microbiol. 2003, 69, 3137-3143. [CrossRef] [PubMed] 
39. Moorhead, S.M.; Dykes, G.A. Influence of the sigB gene on the cold stress survival and subsequent recovery of two Listeria monocytogenes serotypes. Int. J. Food Microbiol. 2004, 91, 63-72. [CrossRef]

40. Zoz, F.; Grandvalet, C.; Lang, E.; Iaconelli, C.; Gervais, P.; Firmesse, O.; Guyot, S.; Beney, L. Listeria monocytogenes ability to survive desiccation: Influence of serotype, origin, virulence, and genotype. Int. J. Food Microbiol. 2017, 248, 82-89. [CrossRef] [PubMed]

41. Møretrø, T.; Langsrud, S. Listeria monocytogenes: Biofilm formation and persistence in food-processing environments. Biofilms 2004, 1, 107-121. [CrossRef]

42. Doijad, S.P.; Barbuddhe, S.B.; Garg, S.; Poharkar, K.V.; Kalorey, D.R.; Kurkure, N.V.; Rawool, D.B.; Chakraborty, T. Biofilm-forming abilities of listeria monocytogenes serotypes isolated from different sources. PLoS ONE 2015, 10, e0137046. [CrossRef] [PubMed]

43. Chmielewski, R.A.N.; Frank, J.F. Biofilm Formation and Control in Food Processing Facilities. Compr. Rev. Food Sci. Food Saf. 2003, 2, 22-32. [CrossRef]

44. Martín, B.; Perich, A.; Gómez, D.; Yangüela, J.; Rodríguez, A.; Garriga, M.; Aymerich, T. Diversity and distribution of Listeria monocytogenes in meat processing plants. Food Microbiol. 2014, 44, 119-127. [CrossRef] [PubMed]

45. Wiedmann, M.; Bruce, J.L.; Knorr, R.; Bodis, M.; Cole, E.M.; McDowell, C.I.; McDonough, P.L.; Batt, C.A. Ribotype diversity of Listeria monocytogenes strains associated with outbreaks of listeriosis in ruminants. J. Clin. Microbiol. 1996, 34, 1086-1090. [PubMed]

46. Fenlon, D.R.; Wilson, J.; Donachie, W. The incidence and level of Listeria monocytogenes contamination of food sources at primary production and initial processing. J. Appl. Bacteriol. 1996, 81, 641-650. [CrossRef] [PubMed]

47. Nightingale, K.K.; Schukken, Y.H.; Nightingale, C.R.; Fortes, E.D.; Ho, A.J.; Her, Z.; Grohn, Y.T.; McDonough, P.L.; Wiedmann, M. Ecology and transmission of Listeria monocytogenes infecting ruminants and in the farm environment. Appl. Environ. Microbiol. 2004, 70, 4458-4467. [CrossRef] [PubMed]

48. Castro, H.K.; Lindström, M. Ecology and surveillance of Listeria monocytogenes on dairy cattle farms. Int. J. Infect. Dis. 2016, 53, 68. [CrossRef]

49. Sauders, B.D.; Overdevest, J.; Fortes, E.; Windham, K.; Schukken, Y.; Lembo, A.; Wiedmann, M. Diversity of Listeria species in urban and natural environments. Appl. Environ. Microbiol. 2012, 78, 4420-4433. [CrossRef] [PubMed]

50. Vivant, A.-L.; Garmyn, D.; Piveteau, P. Listeria monocytogenes, a down-to-earth pathogen. Front. Cell. Infect. Microbiol. 2013, 3, 87. [CrossRef] [PubMed]

51. Linke, K.; Rückerl, I.; Brugger, K.; Karpiskova, R.; Walland, J.; Muri-Klinger, S.; Tichy, A.; Wagner, M.; Stessl, B. Reservoirs of Listeria species in three environmental ecosystems. Appl. Environ. Microbiol. 2014, 80, 5583-5592. [CrossRef] [PubMed]

52. Lianou, A.; Sofos, J.N. A Review of the Incidence and Transmission of Listeria monocytogenes in Ready-to-Eat Products in Retail and Food Service Environments. J. Food Prot. 2007, 70, 2172-2198. [CrossRef] [PubMed]

53. Hoelzer, K.; Oliver, H.F.; Kohl, L.R.; Hollingsworth, J.; Wells, M.T.; Wiedmann, M. Structured Expert Elicitation about Listeria monocytogenes Cross-Contamination in the Environment of Retail Deli Operations in the United States. Risk Anal. 2012, 32, 1139-1156. [CrossRef] [PubMed]

54. Endrikat, S.; Gallagher, D.; Pouillot, R.; Quesenberry, H.H.; Labarre, D.; Schroeder, C.M.; Kause, J. A comparative risk assessment for Listeria monocytogenes in prepackaged versus retail-sliced deli meat. J. Food Prot. 2010, 73, 612-619. [CrossRef]

55. Chaitiemwong, N.; Hazeleger, W.C.; Beumer, R.R.; Zwietering, M.H. Quantification of transfer of Listeria monocytogenes between cooked ham and slicing machine surfaces. Food Control 2014, 44, 177-184. [CrossRef]

56. Scollon, A.M.; Wang, H.; Ryser, E.T. Transfer of Listeria monocytogenes during mechanical slicing of onions. Food Control 2016, 65, 160-167. [CrossRef]

57. Hoelzer, K.; Sauders, B.D.; Sanchez, M.D.; Olsen, P.T.; Pickett, M.M.; Mangione, K.J.; Rice, D.H.; Corby, J.; Stich, S.; Fortes, E.D.; et al. Prevalence, distribution, and diversity of Listeria monocytogenes in retail environments, focusing on small establishments and establishments with a history of failed inspections. J. Food Prot. 2011, 74, 1083-1095. [CrossRef] [PubMed]

58. Lakicevic, B.; Nastasijevic, I. Listeria monocytogenes in retail establishments: Contamination routes and control strategies. Food Rev. Int. 2017, 33, 247-269. [CrossRef] 
59. Zeng, W.; Vorst, K.; Brown, W.; Marks, B.P.; Jeong, S.; Pérez-Rodríguez, F.; Ryser, E.T. Growth of Escherichia coli O157:H7 and Listeria monocytogenes in Packaged Fresh-Cut Romaine Mix at Fluctuating Temperatures during Commercial Transport, Retail Storage, and Display. J. Food Prot. 2014, 77, 197-206. [CrossRef] [PubMed]

60. Azevedo, I.; Regalo, M.; Mena, C.; Almeida, G.; Carneiro, L.; Teixeira, P.; Hogg, T.; Gibbs, P.A. Incidence of Listeria spp. in domestic refrigerators in Portugal. Food Control 2005, 16, 121-124. [CrossRef]

61. Beumer, R.R.; te Giffel, M.C.; Spoorenberg, E.; Rombouts, F.M. Listeria species in domestic environments. Epidemiol. Infect. 1996, 117, 437-442. [CrossRef] [PubMed]

62. Jackson, V.; Blair, I.S.; McDowell, D.A.; Kennedy, J.; Bolton, D.J. The incidence of significant foodborne pathogens in domestic refrigerators. Food Control 2007, 18, 346-351. [CrossRef]

63. Lin, C.-M.; Fernando, S.Y.; Wei, C. Occurrence of Listeria monocytogenes. Salmonella spp., Escherichia coli and E. coli O157:H7 in vegetable salads. Food Control 1996, 7, 135-140. [CrossRef]

64. Soriano, J.M.; Rico, H.; Moltó, J.C.; Mañes, J. Listeria species in raw and ready-to-eat foods from restaurants. J. Food Prot. 2001, 64, 551-553. [CrossRef] [PubMed]

65. Barkley, J.S.; Gosciminski, M.; Miller, A. Whole-genome sequencing detection of ongoing Listeria contamination at a restaurant, Rhode Island, USA, 2014. Emerg. Infect. Dis. 2016, 22, 1474-1476. [CrossRef] [PubMed]

66. Little, C.L.; Amar, C.F.L.; Awofisayo, A.; Grant, K.A. Hospital-acquired listeriosis associated with sandwiches in the UK: A cause for concern. J. Hosp. Infect. 2012, 82, 13-18. [CrossRef] [PubMed]

67. Cokes, C.; France, A.M.; Reddy, V.; Hanson, H.; Lee, L.; Kornstein, L.; Stavinsky, F.; Balter, S. Serving high-risk foods in a high-risk setting: Survey of hospital food service practices after an outbreak of listeriosis in a hospital. Infect. Control Hosp. Epidemiol. 2011, 32, 380-386. [CrossRef] [PubMed]

68. Martins, I.S.; Da Conceião Faria, F.C.; Miguel, M.A.L.; De Sá Colao Dias, M.P.; Cardoso, F.L.L.; De Gouveia Magalhães, A.C.; Mascarenhas, L.A.; Nouér, S.A.; Barbosa, A.V.; Vallim, D.C.; et al. A cluster of Listeria monocytogenes infections in hospitalized adults. Am. J. Infect. Control 2010, 38, e31-e36. [CrossRef] [PubMed]

69. Lee, H.K.; Abdul Halim, H.; Thong, K.L.; Chai, L.C. Assessment of food safety knowledge, attitude, self-reported practices, and microbiological hand hygiene of food handlers. Int. J. Environ. Res. Public Health 2017, 14, 55. [CrossRef]

70. Akabanda, F.; Hlortsi, E.H.; Owusu-Kwarteng, J. Food safety knowledge, attitudes and practices of institutional food-handlers in Ghana. BMC Public Health 2017, 17, 40. [CrossRef] [PubMed]

71. EFSA; ECDC. The European Union summary report on trends and sources of zoonoses, zoonotic agents and food-borne outbreaks in 2016. EFSA J. 2017, 15, 5077. [CrossRef]

72. Gaulin, C.; Lê, M.; Shum, M.; Fong, D. Disinfectants and Sanitizers for Use on Food Contact Surfaces; National Collaborating Centre for Environmental Health: Vancouver, BC, Canada, 2011; pp. 1-15.

73. Bisbiroulas, P.; Psylou, M.; Iliopoulou, I.; Diakogiannis, I.; Berberi, A.; Mastronicolis, S.K. Adaptational changes in cellular phospholipids and fatty acid composition of the food pathogen Listeria monocytogenes as a stress response to disinfectant sanitizer benzalkonium chloride. Lett. Appl. Microbiol. 2011, 52, 275-280. [CrossRef] [PubMed]

74. Møretrø, T.; Schirmer, B.C.T.; Heir, E.; Fagerlund, A.; Hjemli, P.; Langsrud, S. Tolerance to quaternary ammonium compound disinfectants may enhance growth of Listeria monocytogenes in the food industry. Int. J. Food Microbiol. 2017, 241, 215-224. [CrossRef] [PubMed]

75. Gerba, C.P. Quaternary Ammonium Biocides: Efficacy in Application. Appl. Environ. Microbiol. 2015, 81, 464-469. [CrossRef] [PubMed]

76. Martinez-Suarez, J.V.; Ortiz, S.; López-Alonso, V. Potential impact of the resistance to quaternary ammonium disinfectants on the persistence of Listeria monocytogenes in food processing environments. Front. Microbiol. 2016, 7, 1-8. [CrossRef] [PubMed]

77. Liu, X.; Marrakchi, M.; Jahne, M.; Rogers, S.; Andreescu, S. Real-time investigation of antibiotics-induced oxidative stress and superoxide release in bacteria using an electrochemical biosensor. Free Radic. Biol. Med. 2016, 91, 25-33. [CrossRef] [PubMed]

78. Shapiro, R.S. Antimicrobial-Induced DNA Damage and Genomic Instability in Microbial Pathogens. PLoS Pathog. 2015, 11, e1004678. [CrossRef] [PubMed] 
79. Dutta, V.; Elhanafi, D.; Kathariou, S. Conservation and distribution of the benzalkonium chloride resistance cassette bcrABC in Listeria monocytogenes. Appl. Environ. Microbiol. 2013, 79, 6067-6074. [CrossRef] [PubMed]

80. Aase, B.; Sundheim, G.; Langsrud, S.; Rørvik, L.M. Occurrence of and a possible mechanism for resistance to a quaternary ammonium compound in Listeria monocytogenes. Int. J. Food Microbiol. 2000, 62, 57-63. [CrossRef]

81. Ebner, R.; Stephan, R.; Althaus, D.; Brisse, S.; Maury, M.; Tasara, T. Phenotypic and genotypic characteristics of Listeria monocytogenes strains isolated during 2011-2014 from different food matrices in Switzerland. Food Control 2015, 57, 321-326. [CrossRef]

82. Kovacevic, J.; Ziegler, J.; Walecka-Zacharska, E.; Reimer, A.; Kitts, D.D.; Gilmour, M.W. Tolerance of Listeria monocytogenes to quaternary ammonium sanitizers is mediated by a novel efflux pump encoded by emrE. Appl. Environ. Microbiol. 2015, 82, 939-953. [CrossRef] [PubMed]

83. Müller, A.; Rychli, K.; Muhterem-Uyar, M.; Zaiser, A.; Stessl, B.; Guinane, C.M.; Cotter, P.D.; Wagner, M.; Schmitz-Esser, S. Tn6188-A Novel Transposon in Listeria monocytogenes Responsible for Tolerance to Benzalkonium Chloride. PLoS ONE 2013, 8, e768635. [CrossRef] [PubMed]

84. Müller, A.; Rychli, K.; Zaiser, A.; Wieser, C.; Wagner, M.; Schmitz-Esser, S. The Listeria monocytogenes transposon Tn6188 provides increased tolerance to various quaternary ammonium compounds and ethidium bromide. FEMS Microbiol. Lett. 2014, 361, 166-173. [CrossRef] [PubMed]

85. Yoon, Y.; Lee, H.; Lee, S.; Kim, S.; Choi, K.H. Membrane fluidity-related adaptive response mechanisms of foodborne bacterial pathogens under environmental stresses. Food Res. Int. 2015, 72, 25-36. [CrossRef]

86. Dubois-Brissonnet, F.; Trotier, E.; Briandet, R. The Biofilm Lifestyle Involves an Increase in Bacterial Membrane Saturated Fatty Acids. Front. Microbiol. 2016, 7, 1-8. [CrossRef] [PubMed]

87. Miladi, H.; Ammar, E.; Ben Slama, R.; Sakly, N.; Bakhrouf, A. Influence of freezing stress on morphological alteration and biofilm formation by Listeria monocytogenes: Relationship with cell surface hydrophobicity and membrane fluidity. Arch. Microbiol. 2013, 195, 705-715. [CrossRef] [PubMed]

88. Vaid, R.; Linton, R.H.; Morgan, M.T. Comparison of inactivation of Listeria monocytogenes within a biofilm matrix using chlorine dioxide gas, aqueous chlorine dioxide and sodium hypochlorite treatments. Food Microbiol. 2010, 27, 979-984. [CrossRef] [PubMed]

89. Wei, C.-I.; Cook, D.L.; Kirk, J.R. Use of chlorine compounds in the food industry. Food Technol. 1985, 39, 107-115.

90. Valderrama, W.B.; Mills, E.W.; Cutter, C.N. Efficacy of chlorine dioxide against Listeria monocytogenes in brine chilling solutions. J. Food Prot. 2009, 72, 2272-2277. [CrossRef] [PubMed]

91. El-Kest, S.E.; Marth, E.H. Inactivation of Listeria Monocytogenes by Chlorine. J. Food Prot. 1988, 51, $520-524$. [CrossRef]

92. Brackett, R.E. Antimicrobial effect of chlorine on Listeria monocytogenes. J. Food Prot. 1987, 50, 999-1003. [CrossRef]

93. Taormina, P.J.; Beuchat, L.R. Survival and heat resistance of Listeria monocytogenes after exposure to alkali and chlorine. Appl. Environ. Microbiol. 2001, 67, 2555-2563. [CrossRef] [PubMed]

94. Lundén, J.; Autio, T.; Markkula, A.; Hellström, S.; Korkeala, H. Adaptive and cross-adaptive responses of persistent and non-persistent Listeria monocytogenes strains to disinfectants. Int. J. Food Microbiol. 2003, 82, 265-272. [CrossRef]

95. Aarnisalo, K.; Salo, S.; Miettinen, H.; Suihko, M.-L.; Wirtanen, G.; Autio, T.; Lundén, J.; Korkeala, H.; Sjoberg, A.-M. Bacterial efficiencies of commercial disinfectants against Listeria monocytogenes on surfaces. J. Food Saf. 2000, 20, 237-250. [CrossRef]

96. Bremer, P.J.; Monk, I.; Butler, R. Inactivation of Listeria monocytogenes/Flavobacterium spp. biofilms using chlorine: Impact of substrate, $\mathrm{pH}$, time and concentration. Lett. Appl. Microbiol. 2002, 35, 321-325. [CrossRef] [PubMed]

97. Pan, Y.; Breidt, F.; Kathariou, S. Resistance of Listeria monocytogenes biofilms to sanitizing agents in a simulated food processing environment. Appl. Environ. Microbiol. 2006, 72, 7711-7717. [CrossRef] [PubMed]

98. Folsom, J.P.; Frank, J.F. Chlorine Resistance of Listeria monocytogenes Biofilms and Relationship to Subtype, Cell Density, and Planktonic Cell Chlorine Resistance. J. Food Prot. 2006, 69, 1292-1296. [CrossRef] [PubMed]

99. Norwood, D.E.; Gilmour, A. The growth and resistance to sodium hypochlorite of Listeria monocytogenes in a steady-state multispecies biofilm. J. Appl. Microbiol. 2000, 88, 512-520. [CrossRef] [PubMed]

100. Denyer, S.P.; Stewart, G.S.A.B. Mechanisms of action of disinfectants. Int. Biodeterior. Biodegrad. 1998, 41, 261-268. [CrossRef] 
101. Maillard, J.Y. Bacterial target sites for biocide action. J. Appl. Microbiol. Symp. Suppl. 2002, 92, 16S-27S. [CrossRef]

102. Cotter, P.D.; Hill, C. Surviving the Acid Test: Responses of Gram-Positive Bacteria to Low pH. Microbiol. Mol. Biol. Rev. 2003, 67, 429-453. [CrossRef] [PubMed]

103. Ryan, S.; Hill, C.; Gahan, C.G.M. Acid Stress Responses in Listeria monocytogenes. In Advances in Applied Microbiology; Laskin, A.I., Sariaslani, S., Gadd, G.M., Eds.; Elsevier Academic Press: San Diego, CA, USA, 2008; pp. 67-91.

104. Phan-Thanh, L.; Mahouin, F.; Aligé, S. Acid responses of Listeria monocytogenes. Int. J. Food Microbiol. 2000, 55, 121-126. [CrossRef]

105. Koutsoumanis, K.P.; Kendall, P.A.; Sofos, J.N. Effect of Food Processing-Related Stresses on Acid Tolerance of Listeria monocytogenes. Appl. Environ. Microbiol. 2003, 69, 7514-7516. [CrossRef] [PubMed]

106. Phan-Thanh, L.; Mahouin, F. A proteomic approach to study the acid response in Listeria monocytogenes. Electrophoresis 1999, 20, 2214-2224. [CrossRef]

107. Cotter, P.D.; O'Reilly, K.; Hill, C. Role of the glutamate decarboxylase acid resistance system in the survival of Listeria monocytogenes LO28 in low pH foods. J. Food Prot. 2001, 64, 1362-1368. [CrossRef] [PubMed]

108. Cotter, P.D.; Gahan, C.G.M.; Hill, C. Analysis of the role of the Listeria monocytogenes F0F1-ATPase operon in the acid tolerance response. Int. J. Food Microbiol. 2000, 60, 137-146. [CrossRef]

109. Giotis, E.S.; McDowell, D.A.; Blair, I.S.; Wilkinson, B.J. Role of branched-chain fatty acids in pH stress tolerance in Listeria monocytogenes. Appl. Environ. Microbiol. 2007, 73, 997-1001. [CrossRef] [PubMed]

110. Zhang, Y.; Carpenter, C.E.; Broadbent, J.R.; Luo, X. Influence of habituation to inorganic and organic acid conditions on the cytoplasmic membrane composition of Listeria monocytogenes. Food Control 2015, 55, 49-53. [CrossRef]

111. Saá Ibusquiza, P.; Herrera, J.J.R.; Cabo, M.L. Resistance to benzalkonium chloride, peracetic acid and nisin during formation of mature biofilms by Listeria monocytogenes. Food Microbiol. 2011, 28, 418-425. [CrossRef] [PubMed]

112. Lee, S.; Cappato, L.; Corassin, C.; Cruz, A.; Oliveira, C. Effect of peracetic acid on biofilms formed by Staphylococcus aureus and Listeria monocytogenes isolated from dairy plants. J. Dairy Sci. 2016, 99, 2384-2390. [CrossRef] [PubMed]

113. Hwa, S.; Lee, I.; Barancelli, G.V.; Corassin, C.H.; Rosim, R.E.; Sengling, C.F.; Coppa, C.; Fernandes De Oliveira, C.A. Effect of peracetic acid on biofilms formed by Listeria monocytogenes strains isolated from a Brazilian cheese processing plant. Braz. J. Pharm. Sci. 2017, 53, e00071. [CrossRef]

114. Chorianopoulos, N.; Giaouris, E.; Grigoraki, I.; Skandamis, P.; Nychas, G.J. Effect of acid tolerance response (ATR) on attachment of Listeria monocytogenes Scott A to stainless steel under extended exposure to acid or/and salt stress and resistance of sessile cells to subsequent strong acid challenge. Int. J. Food Microbiol. 2011, 145, 400-406. [CrossRef] [PubMed]

115. Cataldo, G.; Conte, M.P.; Chiarini, F.; Seganti, L.; Ammendolia, M.G.; Superti, F.; Longhi, C. Acid adaptation and survival of Listeria monocytogenes in Italian-style soft cheeses. J. Appl. Microbiol. 2007, 103, 185-193. [CrossRef] [PubMed]

116. Stopforth, J.D.; Samelis, J.; Sofos, J.N.; Kendall, P.A.; Smith, G.C. Biofilm formation by acid-adapted and nonadapted Listeria monocytogenes in fresh beef decontamination washings and its subsequent inactivation with sanitizers. J. Food Prot. 2002, 65, 1717-1727. [CrossRef] [PubMed]

117. Van der Veen, S.; Abee, T. Mixed species biofilms of Listeria monocytogenes and Lactobacillus plantarum show enhanced resistance to benzalkonium chloride and peracetic acid. Int. J. Food Microbiol. 2011, 144, 421-431. [CrossRef] [PubMed]

118. Liu, W.; Røder, H.L.; Madsen, J.S.; Bjarnsholt, T.; Sørensen, S.J.; Burmølle, M. Interspecific bacterial interactions are reflected in multispecies biofilm spatial organization. Front. Microbiol. 2016, 7, 1366. [CrossRef] [PubMed]

119. Giaouris, E.; Heir, E.; Desvaux, M.; Hébraud, M.; Møretrø, T.; Langsrud, S.; Doulgeraki, A.; Nychas, G.-J.; Kačániová, M.; Czaczyk, K.; et al. Intra- and inter-species interactions within biofilms of important foodborne bacterial pathogens. Front. Microbiol. 2015, 6, 841. [CrossRef] [PubMed]

120. Kalmokoff, M.L.; Austin, J.W.; Wan, X.D.; Sanders, G.; Banerjee, S.; Farber, J.M. Adsorption, attachment and biofilm formation among isolates of listeria monocytogenes using model conditions. J. Appl. Microbiol. 2001, 91, 725-734. [CrossRef] [PubMed] 
121. Carpentier, B.; Cerf, O. Review-Persistence of Listeria monocytogenes in food industry equipment and premises. Int. J. Food Microbiol. 2011, 145, 1-8. [CrossRef] [PubMed]

122. Norwood, D.E.; Gilmour, A. The differential adherence capabilities of two Listeria monocytogenes strains in monoculture and multispecies biofilms as a function of temperature. Lett. Appl. Microbiol. 2001, 33, 320-324. [CrossRef] [PubMed]

123. Rodríguez-López, P.; Saá-lbusquiza, P.; Mosquera-Fernández, M.; López-Cabo, M. Listeria monocytogenes—carrying consortia in food industry. Composition, subtyping and numerical characterisation of mono-species biofilm dynamics on stainless steel. Int. J. Food Microbiol. 2015, 206, 84-95. [CrossRef] [PubMed]

124. Bremer, P.J.; Monk, I.; Osborne, C.M. Survival of Listeria monocytogenes attached to stainless steel surfaces in the presence or absence of Flavobacterium spp. J. Food Prot. 2001, 64, 1369-1376. [CrossRef] [PubMed]

125. Carpentier, B.; Chassaing, D. Interactions in biofilms between Listeria monocytogenes and resident microorganisms from food industry premises. Int. J. Food Microbiol. 2004, 97, 111-122. [CrossRef] [PubMed]

126. Nilsson, L.; Hansen, T.B.; Garrido, P.; Buchrieser, C.; Glaser, P.; Knøchel, S.; Gram, L.; Gravesen, A. Growth inhibition of Listeria monocytogenes by a nonbacteriocinogenic Carnobacterium piscicola. J. Appl. Microbiol. 2004. [CrossRef]

127. Bas, S.; Kramer, M.; Stopar, D. Biofilm surface density determines biocide effectiveness. Front. Microbiol. 2017, 8, 2443. [CrossRef] [PubMed]

128. Jahid, I.K.; Ha, S.-D. The Paradox of Mixed-Species Biofilms in the Context of Food Safety. Compr. Rev. Food Sci. Food Saf. 2014, 13, 990-1011. [CrossRef]

129. Midelet, G.; Kobilinsky, A.; Carpentier, B. Construction and analysis of fractional multifactorial designs to study attachment strength and transfer of Listeria monocytogenes from pure or mixed biofilms after contact with a solid model food. Appl. Environ. Microbiol. 2006, 72, 2313-2321. [CrossRef] [PubMed]

130. Sasahara, K.C.; Zottola, E.A. Biofilm formation by Listeria monocytogenes utilizes a primary colonizing microorganism in flowing systems. J. Food Prot. 1993, 56, 1022-1028. [CrossRef]

131. Puga, C.H.; SanJose, C.; Orgaz, B. Spatial distribution of Listeria monocytogenes and Pseudomonas fluorescens in mixed biofilms. In Listeria monocytogenes: Food Sources, Prevalence and Management Strategies; Hambrick, E.C., Ed.; Nova Publishers: New York, NY, USA, 2014; pp. 115-132. ISBN 9781631170546.

132. Saá Ibusquiza, P.; Herrera, J.J.R.; Vázquez-Sánchez, D.; Cabo, M.L. Adherence kinetics, resistance to benzalkonium chloride and microscopic analysis of mixed biofilms formed by Listeria monocytogenes and Pseudomonas putida. Food Control 2012, 25, 202-210. [CrossRef]

133. Papaioannou, E.; Giaouris, E.D.; Berillis, P.; Boziaris, I.S. Dynamics of biofilm formation by Listeria monocytogenes on stainless steel under mono-species and mixed-culture simulated fish processing conditions and chemical disinfection challenges. Int. J. Food Microbiol. 2018, 267, 9-19. [CrossRef] [PubMed]

134. Langsrud, S.; Sidhu, M.S.; Heir, E.; Holck, A.L. Bacterial disinfectant resistance-A challenge for the food industry. Int. Biodeterior. Biodegrad. 2003, 51, 283-290. [CrossRef]

135. Ortega Morente, E.; Fernández-Fuentes, M.A.; Grande Burgos, M.J.; Abriouel, H.; Pérez Pulido, R.; Gálvez, A. Biocide tolerance in bacteria. Int. J. Food Microbiol. 2013, 162, 13-25. [CrossRef] [PubMed]

136. Frentzel, H.; Menrath, A.; Tomuzia, K.; Braeunig, J.; Appel, B. Decontamination of High-risk Animal and Zoonotic Pathogens. Biosecur. Bioterror. Biodef. Strateg. Pract. Sci. 2013, 11, S102-S114. [CrossRef] [PubMed]

137. Simões, M.; Simões, L.C.; Vieira, M.J. A review of current and emergent biofilm control strategies. LWT Food Sci. Technol. 2010, 43, 573-583. [CrossRef]

138. Coughlan, L.M.; Cotter, P.D.; Hill, C.; Alvarez-ordóñez, A. New weapons to fight old enemies: Novel strategies for the (bio)control of bacterial biofilms in the food industry. Front. Microbiol. 2016, 7, 1-21. [CrossRef] [PubMed]

139. Oloketuyi, S.F.; Khan, F. Inhibition strategies of Listeria monocytogenes biofilms-Current knowledge and future outlooks. J. Basic Microbiol. 2017, 57, 728-743. [CrossRef] [PubMed]

140. Møretrø, T.; Langsrud, S. Residential Bacteria on Surfaces in the Food Industry and Their Implications for Food Safety and Quality. Compr. Rev. Food Sci. Food Saf. 2017, 16, 1022-1041. [CrossRef]

141. Fox, E.M.; Solomon, K.; Moore, J.E.; Wall, P.G.; Fanning, S. Phylogenetic profiles of in-house microflora in drains at a food production facility: Comparison and biocontrol implications of listeria-positive and -negative bacterial populations. Appl. Environ. Microbiol. 2014, 80, 3369-3374. [CrossRef] [PubMed]

142. O'Sullivan, L.; Ross, R.P.; Hill, C. Potential of bacteriocin-producing lactic acid bacteria for improvements in food safety and quality. Biochimie 2002, 84, 593-604. [CrossRef] 
143. Castellano, P.; Pérez Ibarreche, M.; Blanco Massani, M.; Fontana, C.; Vignolo, G. Strategies for Pathogen Biocontrol Using Lactic Acid Bacteria and Their Metabolites: A Focus on Meat Ecosystems and Industrial Environments. Microorganisms 2017, 5, 38. [CrossRef] [PubMed]

144. Fontana, C.; Cocconcelli, P.S.; Vignolo, G.; Saavedra, L. Occurrence of antilisterial structural bacteriocins genes in meat borne lactic acid bacteria. Food Control 2015, 47, 53-59. [CrossRef]

145. Bower, C.K.; McGuire, J.; Daeschel, M.A. Suppression of Listeria monocytogenes colonization following adsorption of nisin onto silica surfaces. Appl. Environ. Microbiol. 1995, 61, 992-997. [PubMed]

146. Minei, C.C.; Gomes, B.C.; Ratti, R.P.; D'Angelis, C.E.M.; De Martinis, E.C.P. Influence of peroxyacetic acid and nisin and coculture with Enterococcus faecium on Listeria monocytogenes biofilm formation. J. Food Prot. 2008, 71, 634-638. [CrossRef] [PubMed]

147. Bolocan, A.S.; Pennone, V.; O'Connor, P.M.; Coffey, A.; Nicolau, A.I.; McAuliffe, O.; Jordan, K. Inhibition of Listeria monocytogenes biofilms by bacteriocin-producing bacteria isolated from mushroom substrate. J. Appl. Microbiol. 2017, 122, 279-293. [CrossRef] [PubMed]

148. Al-Seraih, A.; Belguesmia, Y.; Baah, J.; Szunerits, S.; Boukherroub, R.; Drider, D. Enterocin B3A-B3B produced by LAB collected from infant faeces: Potential utilization in the food industry for Listeria monocytogenes biofilm management. Antonie van Leeuwenhoek 2017, 110, 205-219. [CrossRef] [PubMed]

149. Caballero Gómez, N.; Abriouel, H.; Grande, M.J.; Pérez Pulido, R.; Gálvez, A. Effect of enterocin AS-48 in combination with biocides on planktonic and sessile Listeria monocytogenes. Food Microbiol. 2012, 30, 51-58. [CrossRef] [PubMed]

150. Winkelströter, L.K.; Gomes, B.C.; Thomaz, M.R.S.; Souza, V.M.; De Martinis, E.C.P. Lactobacillus sakei 1 and its bacteriocin influence adhesion of Listeria monocytogenes on stainless steel surface. Food Control 2011, 22, 1404-1407. [CrossRef]

151. Leriche, V.; Chassaing, D.; Carpentier, B. Behaviour of L. monocytogenes in an artificially made biofilm of a nisin-producing strain of Lactococcus lactis. Int. J. Food Microbiol. 1999, 51, 169-182. [CrossRef]

152. Habimana, O.; Meyrand, M.; Meylheuc, T.; Kulakauskas, S.; Briandet, R. Genetic features of resident biofilms determine attachment of Listeria monocytogenes. Appl. Environ. Microbiol. 2009, 75, 7814-7821. [CrossRef] [PubMed]

153. Zhao, T.; Doyle, M.P.; Zhao, P. Control of Listeria monocytogenes in a biofilm by competitive-exclusion microorganisms. Appl. Environ. Microbiol. 2004, 70, 3996-4003. [CrossRef] [PubMed]

154. Zhao, T.; Podtburg, T.C.; Zhao, P.; Chen, D.; Baker, D.A.; Cords, B.; Doyle, M.P. Reduction by competitive bacteria of Listeria monocytogenes in biofilms and Listeria bacteria in floor drains in a ready-to-eat poultry processing plant. J. Food Prot. 2013, 76, 601-607. [CrossRef] [PubMed]

155. García-Almendárez, B.E.; Cann, I.K.O.; Martin, S.E.; Guerrero-Legarreta, I.; Regalado, C. Effect of Lactococcus lactis UQ2 and its bacteriocin on Listeria monocytogenes biofilms. Food Control 2008, 19, 670-680. [CrossRef]

156. Guerrieri, E.; de Niederhäusern, S.; Messi, P.; Sabia, C.; Iseppi, R.; Anacarso, I.; Bondi, M. Use of lactic acid bacteria (LAB) biofilms for the control of Listeria monocytogenes in a small-scale model. Food Control 2009, 20, 861-865. [CrossRef]

157. Ratti, R.P.; Gomes, B.C.; Martinez, R.C.R.; Souza, V.M.; Martinis, E.C.P. De Elongated cells of Listeria monocytogenes in biofilms in the presence of sucrose and bacteriocin-producing Leuconostoc mesenteroides A11. Ciênc. Tecnol. Aliment. 2010, 30, 1011-1016. [CrossRef]

158. Pérez-Ibarreche, M.; Castellano, P.; Leclercq, A.; Vignolo, G. Control of Listeria monocytogenes biofilms on industrial surfaces by the bacteriocin-producing Lactobacillus sakei CRL1862. FEMS Microbiol. Lett. 2016, 363, 1-6. [CrossRef] [PubMed]

159. Ndahetuye, J.B.; Koo, O.K.; O’bryan, C.A.; Ricke, S.C.; Crandall, P.G. Role of Lactic Acid Bacteria as a Biosanitizer to Prevent Attachment of Listeria monocytogenes F6900 on Deli Slicer Contact Surfaces. J. Food Prot. 2012, 75, 1429-1436. [CrossRef] [PubMed]

160. Woo, J.; Ahn, J. Probiotic-mediated competition, exclusion and displacement in biofilm formation by food-borne pathogens. Lett. Appl. Microbiol. 2013, 56, 307-313. [CrossRef] [PubMed]

161. Winkelströter, L.K.; Tulini, F.L.; De Martinis, E.C.P. Identification of the bacteriocin produced by cheese isolate Lactobacillus paraplantarum FT259 and its potential influence on Listeria monocytogenes biofilm formation. LWT Food Sci. Technol. 2015, 64, 586-592. [CrossRef]

162. Kanmani, P.; Satish Kumar, R.; Yuvaraj, N.; Paari, K.A.; Pattukumar, V.; Arul, V. Probiotics and Its Functionally Valuable Products-A Review. Crit. Rev. Food Sci. Nutr. 2013, 53, 641-658. [CrossRef] [PubMed] 
163. Guillier, L.; Stahl, V.; Hezard, B.; Notz, E.; Briandet, R. Modelling the competitive growth between Listeria monocytogenes and biofilm microflora of smear cheese wooden shelves. Int. J. Food Microbiol. 2008, 128, 51-57. [CrossRef] [PubMed]

164. Habimana, O.; Guillier, L.; Kulakauskas, S.; Briandet, R. Spatial competition with Lactococcus lactis in mixed-species continuous-flow biofilms inhibits Listeria monocytogenes growth. Biofouling 2011, 27, 1065-1072. [CrossRef] [PubMed]

165. Arevalos-Sánchez, M.; Regalado, C.; Martin, S.E.; Domínguez-Domínguez, J.; García-Almendárez, B.E. Effect of neutral electrolyzed water and nisin on Listeria monocytogenes biofilms, and on listeriolysin $\mathrm{O}$ activity. Food Control 2012, 24, 116-122. [CrossRef]

166. Henriques, A.R.; Fraqueza, M.J. Biofilm-forming ability and biocide susceptibility of Listeria monocytogenes strains isolated from the ready-to-eat meat-based food products food chain. LWT Food Sci. Technol. 2017, 81, 180-187. [CrossRef]

167. Camargo, A.C.; de Paula, O.A.L.; Todorov, S.D.; Nero, L.A. In Vitro Evaluation of Bacteriocins Activity Against Listeria monocytogenes Biofilm Formation. Appl. Biochem. Biotechnol. 2016, 178, 1239-1251. [CrossRef] [PubMed]

168. Ming, X.; Daeschel, M.A. Nisin Resistance of Foodborne Bacteria and the Specific Resistance Responses of Listeria monocytogenes Scott A. J. Food Prot. 1993, 56, 944-948. [CrossRef]

169. Crandall, A.D.; Montville, T.J. Nisin Resistance in Listeria monocytogenes ATCC 700302 Is a Complex Phenotype. Appl. Environ. Microbiol. 1998, 64, 231-237. [PubMed]

170. Zhao, T.; Podtburg, T.C.; Zhao, P.; Schmidt, B.E.; Baker, D.A.; Cords, B.; Doyle, M.P. Control of Listeria spp. by competitive-exclusion bacteria in floor drains of a poultry processing plant. Appl. Environ. Microbiol. 2006, 72, 3314-3320. [CrossRef] [PubMed]

171. Schöbitz, R.; González, C.; Villarreal, K.; Horzella, M.; Nahuelquín, Y.; Fuentes, R. A biocontroller to eliminate Listeria monocytogenes from the food processing environment. Food Control 2014, 36, 217-223. [CrossRef]

172. Chi-Zhang, Y.; Yam, K.L.; Chikindas, M.L. Effective control of Listeria monocytogenes by combination of nisin formulated and slowly released into a broth system. Int. J. Food Microbiol. 2004, 90, 15-22. [CrossRef]

173. Gravesen, A.; Kallipolitis, B.; Holmstrøm, K.; Høiby, P.E.; Ramnath, M.; Knøchel, S. pbp2229-Mediated Nisin Resistance Mechanism in Listeria monocytogenes Confers Cross-Protection to Class IIa Bacteriocins and Affects Virulence Gene Expression. Appl. Environ. Microbiol. 2004, 70, 1669-1679. [CrossRef] [PubMed]

174. Naghmouchi, K.; Kheadr, E.; Lacroix, C.; Fliss, I. Class I/Class IIa bacteriocin cross-resistance phenomenon in Listeria monocytogenes. Food Microbiol. 2007, 24, 718-727. [CrossRef] [PubMed]

175. Belguesmia, Y.; Madi, A.; Sperandio, D.; Merieau, A.; Feuilloley, M.; Prévost, H.; Drider, D.; Connil, N. Growing insights into the safety of bacteriocins: The case of enterocin S37. Res. Microbiol. 2011, 162, 159-163. [CrossRef] [PubMed]

176. Marder, E.P.; Griffin, P.M.; Cieslak, P.R.; Dunn, J.; Hurd, S.; Jervis, R.; Lathrop, S.; Muse, A.; Ryan, P.; Smith, K.; et al. Preliminary Incidence and Trends of Infection with Pathogens Transmitted Commonly through Food-Foodborne Diseases Active Surveillance Network, 10 U.S. Sites, 2006-2017. Morb. Mortal. Wkly. Rep. 2018, 64, 324-328. [CrossRef] [PubMed]

177. Nguyen, U.T.; Burrows, L.L. DNase I and proteinase K impair Listeria monocytogenes biofilm formation and induce dispersal of pre-existing biofilms. Int. J. Food Microbiol. 2014, 187, 26-32. [CrossRef] [PubMed]

178. Gray, J.A.; Chandry, P.S.; Kaur, M.; Kocharunchitt, C.; Bowman, J.P.; Fox, E.M. Novel Biocontrol Methods for Listeria monocytogenes Biofilms in Food Production Facilities. Front. Microbiol. 2018, 9, 605. [CrossRef] [PubMed]

179. Rodríguez-López, P.; Puga, C.H.; Orgaz, B.; Cabo, M.L. Quantifying the combined effects of pronase and benzalkonium chloride in removing late-stage Listeria monocytogenes-Escherichia coli dual-species biofilms. Biofouling 2017, 33, 690-702. [CrossRef] [PubMed]

(C) 2018 by the authors. Licensee MDPI, Basel, Switzerland. This article is an open access article distributed under the terms and conditions of the Creative Commons Attribution (CC BY) license (http://creativecommons.org/licenses/by/4.0/). 